Harvey, P. (2009) Towards Good Humanitarian Government: The Role of the Affected State in Disaster Response. Humanitarian Policy Groups Report, Overseas Development Institute.

Nader, L., Savinar, R. (2016) Humanitarianism as Pretext: Defining What Is Moral and Just. In: De Lauri, A. ed. The Politics of Humanitarianism. Power, Ideology and Aid. I.B. Tauris.

ocHA (United Nations Office for the Coordination of Humanitarian Affairs) (2007) Guidelines on the Use of Military and Civil Defense Assets in Disaster Relief. www .unocha.org.

Pandolfi, M. (2003) Contract of Mutual (in)Difference and the Humanitarian Apparatus in Contemporary Albania and Kosovo. Indiana Journal of Global Legal Studies, $10(1): 369-381$.

Yuhas, A. (2015) The Red Cross, Haiti and the "Black Hole" of Accountability for International Aid. The Guardian, June 5.

\title{
Human Dignity
}

Human dignity relates to myriad of meanings across different cultural contexts and time frames (Habermas 2010; Kateb 2011). Its current use, which is codified within international law as a legal principle, a utilitarian and universal ideal, is located within Eurocentric epistemologies of rights and personhood. In this sense, its origins have both Roman and Greek roots. As a construct, the notion "human dignity" conjoins the predicate "human" and the noun "dignity," which draws on the Latin expressions humus for human, decus for dignity, and on the Greek word dignitas for dignity. But while the idea of human dignity enjoys global acceptance as a basic ethical and legal principle, it is also captured by contextually specific vocabularies embedded in philosophies of moral value, mutual respect, interdependency and conviviality, such as the notions of Ubuntu (South Africa), Ujama (Tanzania), Kizuna (Japan), Satyagraha (India), and Ashia (Southern Cameroons), among others. Any universal use of human dignity must therefore be sensitive to specific contextual understandings and be further subjected to empirical substantiation.

As a key humanitarian concept (Edkins 2003; McCrudden 2008; Meron and Rosas 1991), human dignity refers to the basic act of recognizing another person as a worthy human - that is, the status of human beings that entitles them to respect. It is the basic foundation of every human relationship and is 
manifested differently across various cultural contexts. To be human is to have dignity, which Italian scholar Giorgio Agamben (1998) refers to as more than just bare life: a respectable and respected social being, rather than just a brute biological organism. It is a grounding justification for all the actions undertaken to protect and preserve human welfare.

Human dignity became one of the most significant constructs of humanitarianism after the end of World War II and is now protected in almost every internal law and domestic jurisdiction. It became an institutionalized practice after the Holocaust and the founding of the United Nations system. Within this context, "human" was defined as a particular kind of liberal individual requiring protection. In international law, human dignity is articulated as a right and is enshrined in the 1948 Universal Declaration of Human Rights.

At the individual level, human dignity refers to a sense of pride over one's self-worth and value, often operationalized by development agencies and national governments as a cultivation of individual capabilities. Collectively, it is a moral obligation embedded in an ethics of care that spells out the conditions through which people get processed as valuable humans deserving of recognition - that is, the terms by which a person gains recognition as a full and equal human being.

Although they are premised on the notion of human dignity and equality, humanitarian interventions are not always distributed equally. Therefore, some scholars argue that they are part of a broader matrix of political projects, where there is more urgency to salvage some groups' human dignity than that of others. This can be referred to as the inequality of humanitarianism, situated within a narrow recognition of a status as citizen with specific rights, privileges, and obligations. This is embedded in the thesis, to paraphrase George Orwell (1945), that while all humans are equal, some are more equal than others, and therefore the responsibility to protect them is more urgent-hence creating a hierarchy of suffering and being.

Today, dignity is a deeply contested construct with shifting interpretations, and not only the prerogative of humans, as seen in instruments protecting the dignity of plants, animals, and, more recently, robots. It is also invoked in bioethical debates and a core element of instruments concerned with biotechnology, biomedicine and artificial intelligence, calling for a concept of dignity that is inclusive of posthumans (Beyleveld 2001; Bostrom 2005).

\section{Divine Fuh}




\section{References}

Agamben, G. (1998) Homo Sacer: Sovereign Power and Bare Life. Stanford University Press.

Beyleveld, D. (2001) Human Dignity in Bioethics and Biolaw. Oxford University Press.

Bostrom, N. (2005) In Defense of Posthuman Dignity. Bioethics, 19(3): 202-214.

Edkins, J. (2003) Humanitarianism, Humanity, Human. Journal of Human Rights, 2(2): $253^{-258 .}$

Habermas, J. (2010) The Concept of Human Dignity and the Realistic Utopia of Human Rights. Metaphilosophy, 41(4): 464-480.

Kateb, G. (2011) Human Dignity. Harvard University Press.

McCrudden, C. (2008) Human Dignity and Judicial Interpretation of Human Rights. European Journal of International Law, 19(4): 655-724.

Meron, T., Rosas, A. (1991) A Declaration of Minimum Humanitarian Standards. American Journal of International Law, 85(2): 375-381.

Orwell, G. (1945) Animal Farm. Secker \& Warburg.

\section{Human Rights}

Human rights are a discourse and ideology around which a massive global phenomenon has formed since World War II. This phenomenon encompasses the human rights community, including human rights experts and activists, and artifacts including human rights covenants, policy papers, and reports. The core of human rights ideology rests on the ideas of equality and emancipation, and is further anchored in the universalizing category of "everyone," a gender-neutral and all-encompassing term that eludes distinctions on the basis of nationality or other criteria. At the same time, human rights can be conceptualized as entities protecting the individual against the arbitrary treatment of the sovereign, whether embodied by a monarch, state, tribe, clan, or family.

In their emphasis on the individual, human rights are connected to international humanitarian law, which likewise places its emphasis on the individual, not on states, which are the primary subjects of international law. Both human rights and international humanitarian law also aim to find different ways of protecting the individual. Yet the temporality and overall vision of human 